\title{
PLANT SPECIES RICHNESS AND DIVERSITY IN NATURAL BEECH AND OAK DOMINATED FORESTS OF KOSMAJ PROTECTED AREA (SERBIA)
}

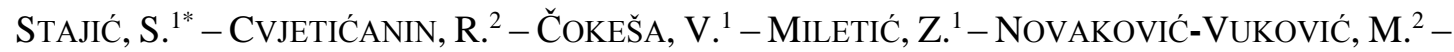 \\ EREMIJA, S. ${ }^{1}-$ RAKONJAC, LJ. $^{1}$ \\ ${ }^{1}$ Institute of Forestry, Kneza Viseslava 3, 11000 Belgrade, Serbia \\ (phone: +381-11-3553-355; fax: +381-11-254-5969) \\ ${ }^{2}$ Faculty of Forestry, University of Belgrade, 11000 Belgrade, Serbia \\ (phone: +381-11-305-3990; fax: +381-11-254-5485) \\ *Corresponding author \\ e-mail: snezanastajic@yahoo.com \\ (Received $8^{\text {th }}$ Mar 2021; accepted $14^{\text {th }}$ May 2021)
}

\begin{abstract}
This study compares plant species richness and diversity of beech and oak-dominated forests in the protected area of Kosmaj Mountain (Serbia). From the aspect of syntaxonomy, the forest vegetation of this area consists of deciduous oak and beech forests of the Querco-Fagetea class. A total of 76 phytosociological relevés were used in the analysis of the floristic composition of mixed broadleaved forests. We determined six forest communities dominated by different oak species (Quercus cerris L., Quercus farnetto Ten., Quercus petraea (Matt.) Liebl.) and beech (Fagus sylvatica L.). A total of 52 families, 133 genera, and 216 species were recorded. The average number of species per forest community ranged from 21 to 38 . The Shannon-Wiener index $\left(H^{\prime}\right)$ ranged from 2.13 to 3.16 , and the species evenness ranged from 0.69 to 0.85 . The results show that the number of species and diversity are significantly higher in the communities where oaks are edifying species than in the beech-dominated communities. It applies both to monodominant beech and mixed beech and sessile oak forests. The present study will help us understand the patterns of tree species composition and diversity on Kosmaj Mountain, which can serve as a valuable guideline in the management of this protected area to preserve and enhance its biological diversity.
\end{abstract}

Keywords: forest plant communities, floristic composition, Shannon-Wiener index, evenness, Serbia

\section{Introduction}

Despite considerable efforts, biodiversity in European countries is constantly declining. The main reason lies in the destruction of natural habitats caused by the fragmentation of vital areas of flora and fauna. The establishment and maintenance of protected areas is the backbone of global conservation strategies in halting biodiversity loss. (Morales-Hidalgo et al., 2015; Guadilla-Sáez et al., 2019). Bearing in mind the importance of forests for biological diversity and the role of preservation and proper improvement of biological diversity in all types of forests for sustainable management, forest vegetation mapping and monitoring are of high priority in the improvement of protected areas.

Forest communities show the most visible signs of ecosystem degradation since plants produce rapid responses to the disturbances in the ecosystem balance. The diversity of the herb layer is an important indicator of both habitat quality and the impact of management on the environment. Hence the composition, condition, and change in vegetation cover over time are deciding factors in environmental studies and 
nature protection programs (Wohlgemuth et al., 2008; Vanderschaaf et al., 2008; Morales-Hidalgo et al., 2015, Guadilla-Sáez et al., 2019).

The main objective of the research was to study the relationship between plant species richness and diversity in native mixed oak forests and beech forests (pure and mixed beech-sessile oak stands) in the protected area of Kosmaj. Research conducted in protected areas gives a deeper insight into local ecosystems (Pérez-Valladares et al., 2019), giving us the information necessary to improve the management process. At the same time, such research is the basis for the planning of silvicultural measures, which is the decisive factor in the establishment of biologically diverse and stable forest ecosystems.

\section{Material and methods}

\section{Study area}

The research was conducted in the area of Kosmaj Mountain (Fig. 1), which is located $40 \mathrm{~km}$ southeast of the city of Belgrade (Serbia). Kosmaj is a relatively low mountain massif $(626 \mathrm{~m})$, most of which was declared a protected area in 2005 . The total surface area of this protected area is $3,514.50$ ha, of which 688.30 ha is under forest vegetation (latitudes $44^{\circ} 26^{\prime} 32^{\prime \prime}-44^{\circ} 29^{\prime} 11^{\prime \prime} \mathrm{N}$ and longitudes $20^{\circ} 33^{\prime} 05^{\prime \prime}-20^{\circ} 36^{\prime} 04^{\prime \prime} \mathrm{E}$ ).
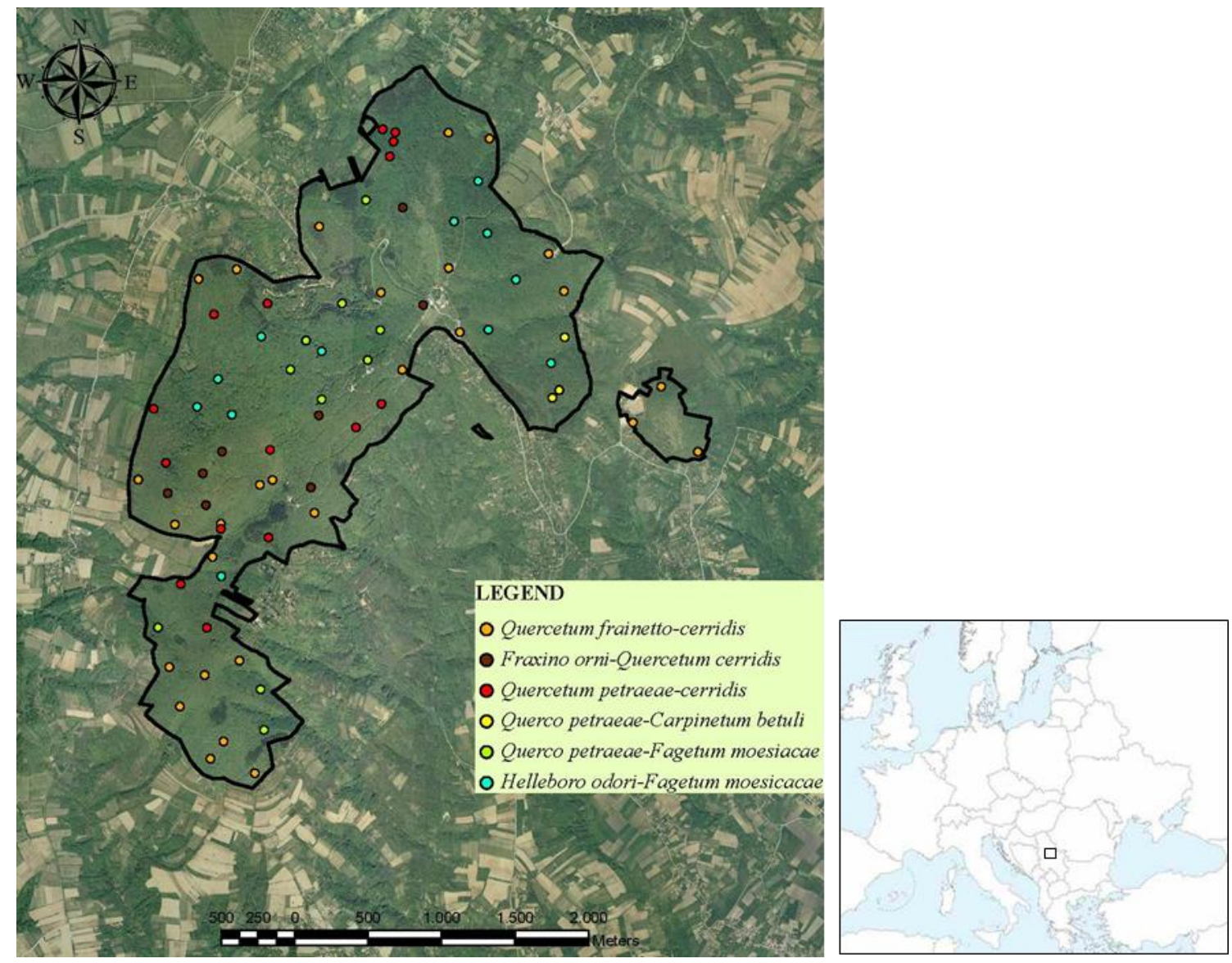

Figure 1. Map of the study area with the locations of the experimental areas 
According to Thorntwhite's climate classification, this area is dominated by moist subhumid climate $-\mathrm{C}_{2}$ type. The mean annual air temperature is $12.3^{\circ} \mathrm{C}$, while it amounts to $18.9^{\circ} \mathrm{C}$ in the growing season. The mean annual rainfall is $696 \mathrm{~mm}$, about $57 \%$ of which falls in the growing season (Stajić, 2016).

In terms of geology, Mount Kosmaj is an isolated island massif of Cretaceous flysch and limestone with several outcrops of serpentinite and granitoid, which has created a significant soil variability of Kosmaj. The specific climate of this transitional area, bedrock, and soil variability, as well as human impact, have formed rich and diverse flora and vegetation dominated by oak and beech forests.

\section{Sampling strategy}

A total of 76 phytosociological relevés were used in the analysis of oak and beech forest floristic composition in the area of Kosmaj. Field surveys were conducted in 2016 and 2017. Floristic sampling was done on a floristically homogeneous surface area with a plot size of $900 \mathrm{~m}^{2}$ (30 x $\left.30 \mathrm{~m}\right)$. In each plot, a complete floristic list of all vascular plants (tree, shrub, and herb layers separately) was recorded using the Braun-Blanquet scale (Braun-Blanquet, 1964). Syntaxonomic names were given according to Tomić and Rakonjac (2013). The transformation of abundance and cover estimation of each species within phytocoenological relevés was performed according to the Van Der Maarel method (1979).

\section{Measurement of plant diversity}

Species richness was determined as the total number of species in the investigated forest communities. Species diversity was measured using the ShannonWiener diversity index (Shannon and Weaver, 1963); the Pielou Index (E) was used for the estimation of species evenness (1975). JUICE 7.0 software was used to calculate these indices (Tichý, 2002).

\section{Statistical analysis}

The multivariate analysis - the method of correspondence analysis (CA) was used to determine how much variability between phytocoenoses can be explained by ordination. The CANOCO 4.5 environmental research software package was the most suitable for this purpose (Lepš and Šmilauer, 2003). Testing the differences in the number of species (species richness), the Shannon-Wiener diversity index $\left(\mathrm{H}^{\prime}\right)$ and the Evenness index between the investigated forest communities was performed using ANOVA analysis of variance in the software package Statistics 6.0. Analysis of variance used the Tukey test at the significance level of 0.05 .

\section{Results}

\section{Forest community types}

From the aspect of syntaxonomy, the forest vegetation of this area belongs to deciduous oak and beech forests of the Querco-Fagetea class. The following six forest communities were distinguished: Hungarian oak and Turkey oak (Quercetum frainettocerridis Rudski 1949), Turkey oak and manna ash (Fraxino orni-Quercetum cerridis Stefanović 1968), sessile oak and Turkey oak (Quercetum petraeae-cerridis B. 
Jovanović 1979), sessile oak and common hornbeam (Querco petraeae-Carpinetum betuli Rudski 1949), sessile oak and beech (Querco petraeae-Fagetum moesiacae Glišić 1971) and beech (Helleboro odori-Fagetum moesiacae Soo \& Borhidi 1960).

Quercetum frainetto-cerridis is the most widespread climax community in Serbia. On Mt. Kosmaj, these thermophilic deciduous forests occupy mainly lower parts (from 300 to $500 \mathrm{~m}$ above sea level), warm exposures, and gentle slopes $\left(6^{\circ}-22^{\circ}\right)$. Plants of xerothermophilic character predominate in this community. The most abundant plant species in the ground cover vegetation are: fragrant hellebore (Helleborus odorus), false brome (Brachypodium sylvaticum), wild basil (Calamintha vulgaris), woodland strawberry (Fragaria vesca) and others (Table 1).

Forests of Turkey oak with manna ash - Fraxino orni-Quercetum cerridis occupy small areas on plateaus and gentle slopes in the highest parts of zonal vegetation (400-600 $\mathrm{m}$ ) with varying exposures (mostly warm) and slopes of $6^{\circ}$ to $23^{\circ}$. The stands have a rare canopy closure, with plenty of light. They are rich in both woody and herbaceous species.

Quercetum petraeae-cerridis communities are found at altitudes of 300-600 m, with varying exposures (more often warm ones) and slightly steeper slopes than the previous communities $\left(8^{\circ}-28^{\circ}\right)$. The floristic richness of these forests is great. A total of 116 species were recorded from 43 families. There are both xerophilous species and mesophilic elements of sessile oak forests.

Querco petraeae-Fagetum moesiacae mixed community is found in the altitude zone of $300-600 \mathrm{~m}$, mostly on the north-facing slopes of $16^{\circ}-26^{\circ}$. The Helleboro odoriFagetum moesiacae community occurs at altitudes ranging from 300 to $600 \mathrm{~m}$, where these forests occupy steep, sheltered slopes and depressions with northern exposures. Beech-dominated communities typically have mesophilic plants in the ground flora layer, although some thermophilic species of adjacent oak forests are also present.

Table 1. The ten most abundant plant species in the ground cover vegetation for each vegetation type

\begin{tabular}{|c|c|c|c|c|c|}
\hline QC & FC & $\mathbf{Q P}$ & QC & QF & HF \\
\hline $\begin{array}{l}\text { Helleborus } \\
\text { odorus }\end{array}$ & Quercus cerris & $\begin{array}{r}\text { Brachyp } \\
\text { syvati }\end{array}$ & Tamus communis & Hedera helix & Fagus sylvatica \\
\hline Quercus cerris & $\begin{array}{l}\text { Brachypodium } \\
\text { sylvaticum }\end{array}$ & Mycelis muralis & $\begin{array}{c}\text { Euphorbia } \\
\text { amygdaloides }\end{array}$ & & $\begin{array}{l}\text { Lamium } \\
\text { galeobdolon }\end{array}$ \\
\hline $\begin{array}{l}\text { Brachypodium } \\
\text { sylvaticum }\end{array}$ & $\begin{array}{c}\text { Helleborus } \\
\text { odorus }\end{array}$ & $\begin{array}{l}\text { Lonicera } \\
\text { caprifolium }\end{array}$ & $\begin{array}{c}\text { Cardamine } \\
\text { bulbifera }\end{array}$ & Viola hirta & $\begin{array}{c}\text { Cardamine } \\
\text { bulbifera }\end{array}$ \\
\hline $\begin{array}{l}\text { Calamintha } \\
\text { vulgaris }\end{array}$ & Fragaria vesca & $\begin{array}{c}\text { Helleborus } \\
\text { odorus }\end{array}$ & $\begin{array}{l}\text { Brachypodium } \\
\text { sylvaticum }\end{array}$ & $\begin{array}{l}\text { Moehr } \\
\text { triner }\end{array}$ & Acer campestre \\
\hline Fragaria vesca & $\begin{array}{l}\text { iragus } \\
\text { ifolius }\end{array}$ & $\begin{array}{l}\text { Crataegus } \\
\text { monogyna }\end{array}$ & Quercus petraea & $\begin{array}{c}\text { Geranium } \\
\text { robertianum }\end{array}$ & $\begin{array}{l}\text { Helleborus } \\
\text { odorus }\end{array}$ \\
\hline Rosa canina & icinalis & Tamus communis & $\begin{array}{l}\text { Ruscus } \\
\text { aculeatus }\end{array}$ & Quercus cerris & Mycelis muralis \\
\hline Rubus canescens & Galium aparine & $\begin{array}{l}\text { Geranium } \\
\text { robertianum }\end{array}$ & Hedera helix & Carex pilosa & $\begin{array}{l}\text { Circaea } \\
\text { lutetiana }\end{array}$ \\
\hline Viola hirta & Viola hirta & Circaea lutetiana & $\begin{array}{l}\text { Glechoma } \\
\text { hirsuta }\end{array}$ & Fagus sylvatica & Stachys silvatica \\
\hline Mycelis muralis & Geum urbanum & Rubus canescens & Carex pilosa & Viola sylvestris & Carex sylvatica \\
\hline Geum urbanum & Rosa canina & $\begin{array}{c}\text { Euphorbia } \\
\text { amygdaloides }\end{array}$ & Carex sylvatica & $\begin{array}{c}\text { Acer } \\
\text { pseudoplatanus }\end{array}$ & $\begin{array}{c}\text { Moehringia } \\
\text { trinervia }\end{array}$ \\
\hline
\end{tabular}

Legend: Quercetum frainetto-cerridis - QC; Fraxino orni-Quercetum cerridis- FC; Quercetum petraeae-cerridis - QP; Querco petraeae-Carpinetum betuli - QC; Querco petraeae-Fagetum moesiacae - QF; Helleboro odori- Fagetum moesiacae- HF 
CA analysis of vegetation data showed the grouping of relevés into two groups. On the one hand, there are oak-dominated forest communities. On the other hand, there are mesophilic communities in which beech is an edifying species (Fig. 2).

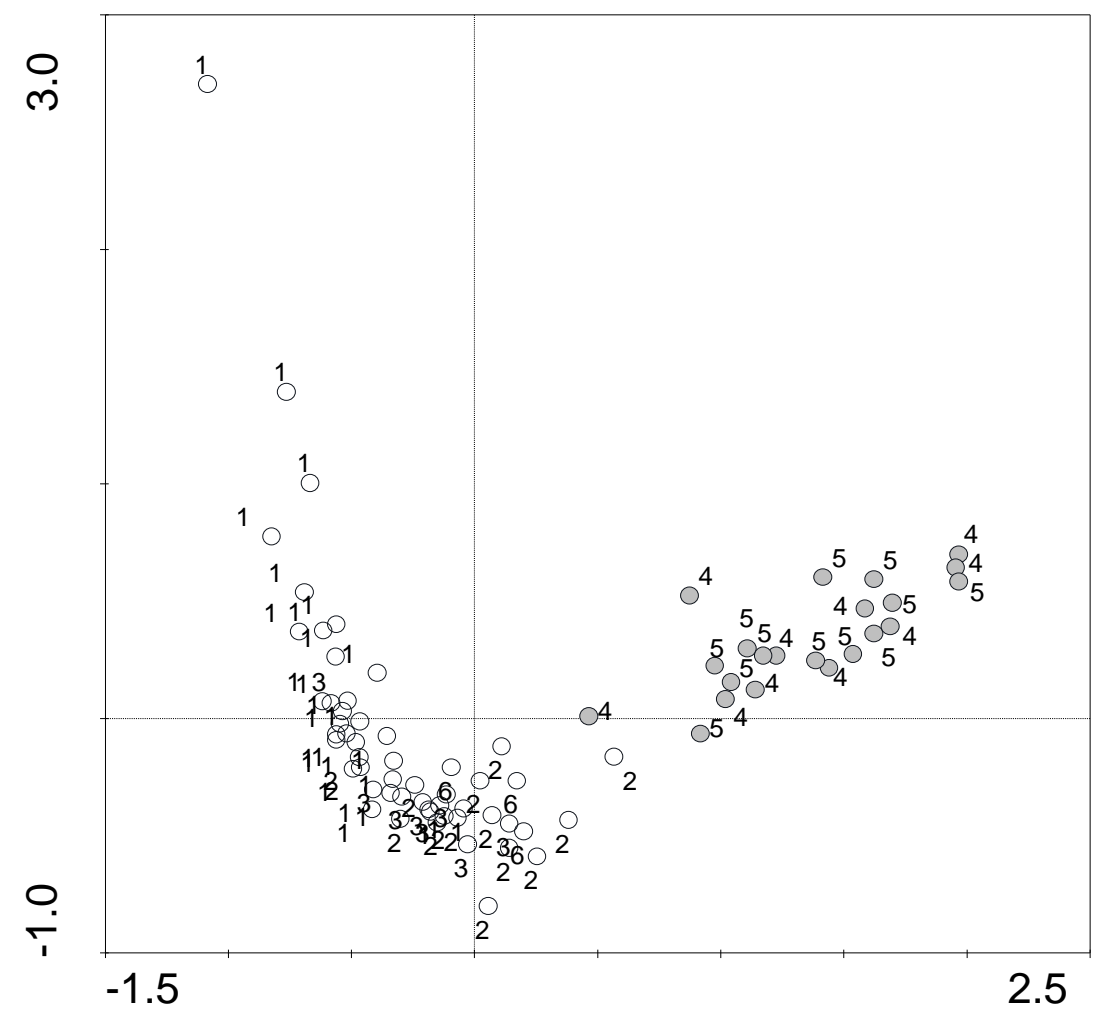

Figure 2. CA ordination biplot for the first two axes of floristic data of forest communities on Kosmaj (1-Quercetum frainetto-cerridis;2-Quercetum petraeae-cerridis;3-Fraxino orniQuercetum cerridis;4-Querco petraeae-Fagetum moesiacae;5-Helleboro odori-Fagetum moesiacae;6-Querco petraeae-Carpinetum betuli)

The relative distance between species and specimens indicates similarities between them, based on which the floristic similarity of individual communities can be determined. There is no clear differentiation within oak communities, which points to a certain floristic similarity of the investigated communities.

On the left side, in the negative part of the graph, there are xerophilous and xeromesophilic species, whose presence is common in Quercetum frainetto-cerridis and Fraxino orni-Quercetum cerridis forests (Fig. 3). These are Stachys recta, Achillea millefolium, Quercus pubescens, Teucrium chamaedrys and Festuca ovina.

Around the middle of the graph, where the relevés of Quercetum petraeae-cerridis and Querco petraeae-Carpinetum betuli communities are located, there are xeromesophilic species that can be found in xerophilous forests but prefer mesophilic habitats: Crataegus monogyna, Geum urbanum, Rosa canina and Brachypodium sylvaticum.

In the positive part of the graph, where relevés of mesophilic beech forests Querco petraeae-Fagetum moesiacae and Helleboro odori-Fagetum moesiacae are concentrated, mesophilic species were determined: Fagus sylvatica, Stachys sylvatica, Circaea lutetiana, while all other species are submezophilic in character. 


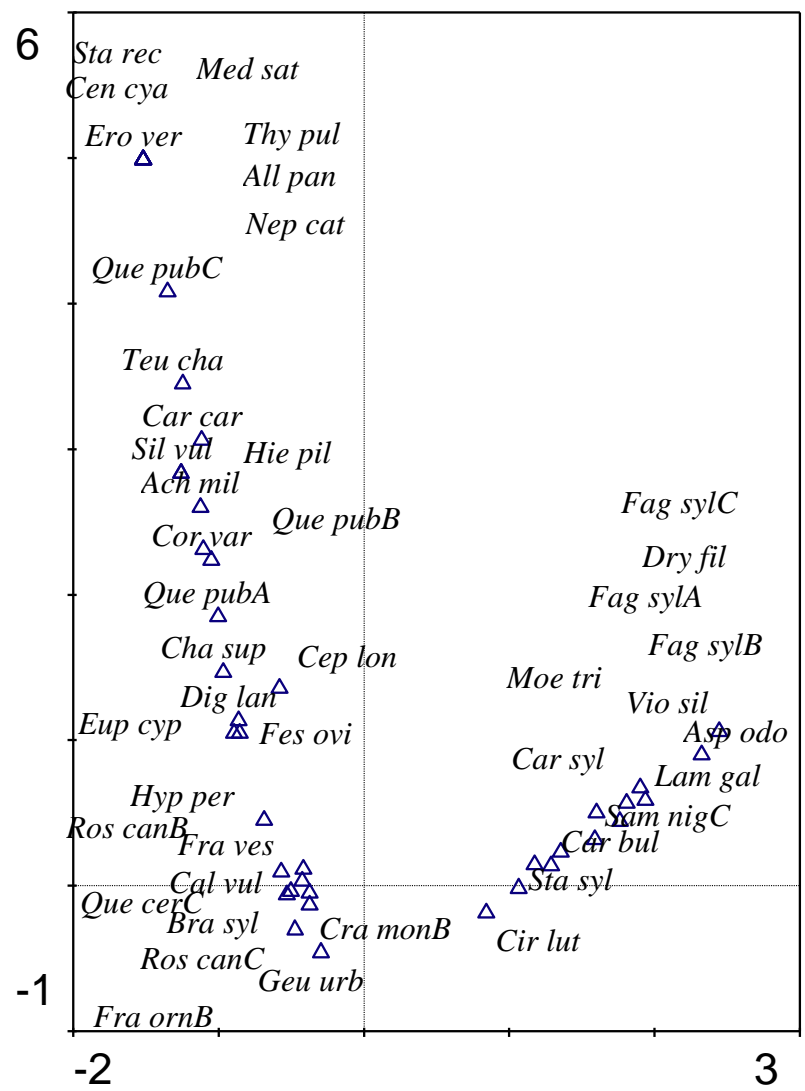

Figure 3. CA ordination biplot for species in forest communities on Mt. Kosmaj (fit range for species $20-100 \%, 44$ species)

Abbreviations for species: Sta rec-Stachys recta; Med sat-Medicago sativa; Cen cay-Centaurea cynaus; Ero ver-Erophyla verna; Thy pul-Thymus pulegioides; All pan-Allium paniculatum; Nep cat-Nepeta cataria; Que pub-Quercus pubescens; Teu cha-Teucrium chamaedrys; Car car-Carex caryophyllea; Sil vul-Silene vulgaris; Hie pil-Hieracium pilosella; Ach mil-Achillea millefolium; Fag syl-Fagus sylvatica; Cor var-Coronilla varia; Dry fil-Dryopteris filix-mas; Cha sup-Chamaecytisus supinus; Cep lonCephalanthera longifolia; Dig lan- Digitalis lanata; Moe tri-Moehringia trinervia; Vio sil-Viola silvestris; Eup cyp-Euphorbia cyparissias; Fes ovi-Festuca ovina; Car syl-Carex sylvatica; Asp odoAsperula odorata; Lam gal-Lamium galeobdolon; Hyp per-Hypericum perforatum; Ros can-Rosa canina; Sam nig-Sambucus nigra; Fra ves- Fragaria vesca; Car bul-Cardamine bulbifera; Cal vulCalamintha vulgaris; Sta syl-Stachys sylvatica; Que cer-Quercus cerris; Bra syl-Brachypodium sylvaticum; Cra mon-Crataegus monogyna; Cir lut-Circaea lutetiana; Geu urb-Geum urbanum; Fra ornFraxinus ornus

(The abbreviation following the species denotes A-tree layer, B-shrub layer, C-herb layer)

\section{Floristic diversity and species composition}

The floristic structure of the investigated forest phytocoenoses of Kosmaj is characterized by biodiversity that comprises 52 families, 133 genera, and 216 plant species (Table 2). More than half of the plant species belong to the following ten families: Rosaceae (23), Lamiaceae (18), Fabaceae (17), Poaceae (15), Asteraceae (12), Apiaceae (10), Scrophulariaceae (9), Brassicaceae (8), Campanulaceae (8), Cyperaceae (8).

The highest total number of species was recorded in the Quercetum frainetto-cerridis community (172), while the Querco petraeae-Carpinetum betuli had the lowest number of species (66). This community is represented by only three experimental areas 
because it can be found in a relatively small surface area. The largest number of families was also recorded in the Quercetum frainetto-cerridis community.

Table 2. Main topographic and floristic characteristics of the investigated forest phytocoenoses

\begin{tabular}{|c|c|c|c|c|c|c|}
\hline & $\begin{array}{l}\text { Quercetum } \\
\text { frainetto- } \\
\text { cerridis }\end{array}$ & $\begin{array}{c}\text { Fraxino } \\
\text { orni- } \\
\text { Quercetum } \\
\text { cerridis }\end{array}$ & $\begin{array}{c}\text { Quercetum } \\
\text { petraeae- } \\
\text { cerridis }\end{array}$ & \begin{tabular}{|c|} 
Querco \\
petraeae- \\
Carpinetum \\
betuli
\end{tabular} & $\begin{array}{c}\text { Querco } \\
\text { petraeae- } \\
\text { Fagetttum } \\
\text { moesiacae }\end{array}$ & $\begin{array}{c}\text { Helleboro } \\
\text { odori- } \\
\text { Fagetum } \\
\text { moesiacae }\end{array}$ \\
\hline Total number of plots & 28 & 8 & 15 & 3 & 10 & 12 \\
\hline Elevation (m) & $336-495$ & $454-567$ & $356-573$ & $339-410$ & $373-585$ & $380-561$ \\
\hline Slope $\left(^{\circ}\right)$ & $6-22$ & $6-23$ & $8-28$ & $15-23$ & $16-26$ & $18-25$ \\
\hline Tree cover $(\%)$ & $70-90$ & $60-80$ & $70-90$ & 80 & $80-100$ & $90-100$ \\
\hline Shrub cover $(\%)$ & $20-90$ & $40-90$ & $10-90$ & $30-80$ & 10 & $10-20$ \\
\hline Herb cover $(\%)$ & $30-90$ & $20-100$ & $30-100$ & $40-70$ & $30-100$ & $20-90$ \\
\hline $\begin{array}{l}\text { Total number of species } \\
\text { recorded in plots }\end{array}$ & 172 & 77 & 116 & 66 & 78 & 73 \\
\hline Number of families & 45 & 35 & 43 & 30 & 42 & 37 \\
\hline $\begin{array}{l}\text { Number of tree species } \\
\text { in the total sampled area }\end{array}$ & 10 & 8 & 13 & 7 & 12 & 7 \\
\hline $\begin{array}{l}\text { Number of shrub species } \\
\text { in the total sampled area }\end{array}$ & 27 & 14 & 24 & 12 & 9 & 5 \\
\hline $\begin{array}{l}\text { Number of herb species } \\
\text { in the total sampled area }\end{array}$ & 166 & 76 & 113 & 59 & 73 & 69 \\
\hline Dominant families & $\begin{array}{l}\text { Rosaceae } \\
\text { Fabaceae } \\
\text { Lamiaceae }\end{array}$ & $\begin{array}{l}\text { Rosaceae } \\
\text { Lamiaceae }\end{array}$ & $\begin{array}{l}\text { Rosaceae } \\
\text { Lamiaceae }\end{array}$ & $\begin{array}{l}\text { Rosaceae } \\
\text { Fagaceae }\end{array}$ & $\begin{array}{l}\text { Rosaceae } \\
\text { Lamiaceae }\end{array}$ & $\begin{array}{l}\text { Fagaceae } \\
\text { Lamiaceae }\end{array}$ \\
\hline
\end{tabular}

\section{Species diversity}

The species richness, Shannon-Wiener diversity index $\left(H^{\prime}\right)$, and species evenness index were used as indicators of species diversity in the investigation of the forest vegetation of Kosmaj.

The mean species richness per plot in the investigated oak communities is significantly higher compared to the beech communities and ranges from 29 in the Fraxino orni-Quercetum cerridis community to a maximum of 38 in the Querco petraeae-Carpinetum betuli community (Table 3). In the communities in which beech is an edifying species, the average number of species per experimental area is 21 in the monodominant beech communities (Helleboro odori-Fagetum moesiacae), and 22 in the mixed sessile oak - beech communities (Querco petraeae-Fagetum moesiacae). The Tukey test showed that there are statistically significant differences in the average number of species between the beech-dominated communities compared to other phytocoenoses, except the Fraxino orni-Quercetum cerridis community.

Monodominant beech communities (Helleboro odori-Fagetum moesiacae) have the lowest average value of the Shannon-Wiener diversity index $\left(H^{\prime}\right)$ and it amounts to 2.13. The value of the index is slightly higher in the mixed community of beech and sessile oak (Querco petraeae-Fagetum moesiacae) and amounts to 2.32. In the oakdominant communities, the $H^{\prime}$ index is significantly higher -2.86 to 3.16 . The Tukey test showed statistically-significant differences in the $H^{\prime}$ index between the investigated beech-dominant communities compared to the oak forest communities. 
The average evenness index of the investigated forest communities varies from a minimum of 0.69 in the Helleboro odori-Fagetum moesiacae community to a maximum of 0.85 in the Querco petraeae-Carpinetum betuli community. The Tukey test showed that there are statistically significant differences in the evenness index between the investigated beech-dominated communities compared to other investigated phytocoenoses.

Table 3. Comparison of species richness, Shannon diversity index and species evenness by vegetation type (mean $\pm 1 S E)$

\begin{tabular}{|c|c|c|c|c|c|c|c|c|c|}
\hline \multirow{2}{*}{$\begin{array}{c}\text { Forest } \\
\text { community type }\end{array}$} & \multicolumn{3}{|c|}{ Species richness } & \multicolumn{3}{|c|}{$\begin{array}{c}\text { Shannon-Wiener diversity } \\
\text { index }\left(H^{\prime}\right)\end{array}$} & \multicolumn{3}{|c|}{ Evenness } \\
\hline & Mean \pm 1SE & Min & Max & Mean $\pm 1 \mathrm{SE}$ & Min & Max & Mean $\pm 1 \mathrm{SE}$ & Min & Max \\
\hline $\begin{array}{c}\text { Quercetum } \\
\text { frainetto-cerridis } \\
\text { Fraxino orni- }\end{array}$ & $35.28^{\mathrm{a}} \pm 1.384$ & 20.00 & 49.00 & $3.04^{\mathrm{a}} \pm 0.038$ & 2.48 & 3.39 & $0.83^{\mathrm{a}} \pm 0.005$ & 0.77 & 0.89 \\
\hline $\begin{array}{l}\text { Quercetum } \\
\text { cerridis }\end{array}$ & $29.12^{\mathrm{ab}} \pm 2.635$ & 18.00 & 40.00 & $2.86^{\mathrm{a}} \pm 0.090$ & 2.51 & 3.20 & $0.82^{\mathrm{a}} \pm 0.009$ & 0.77 & 0.84 \\
\hline $\begin{array}{c}\text { Quercetum } \\
\text { petraeae-cerridis }\end{array}$ & $33.87^{\mathrm{a}} \pm 1.570$ & 23.00 & 45.00 & $2.99^{\mathrm{a}} \pm 0.060$ & 2.43 & 3.34 & $0.82^{\mathrm{a}} \pm 0.011$ & 0.75 & 0.90 \\
\hline $\begin{array}{l}\text { Querco petraeae- } \\
\text { Carpinetum betuli }\end{array}$ & $37.67^{a} \pm 5.207$ & 29.00 & 47.00 & $3.16^{\mathrm{a}} \pm 0.043$ & 3.08 & 3.23 & $0.85^{\mathrm{a}} \pm 0.015$ & 0.82 & 0.87 \\
\hline $\begin{array}{c}\text { Querco petraeae- } \\
\text { Fagetum } \\
\text { moesiacae }\end{array}$ & $21.60^{\mathrm{b}} \pm 1.740$ & 13.00 & 29.00 & $2.32^{\mathrm{b}} \pm 0.123$ & 1.73 & 2.77 & $0.74^{\mathrm{b}} \pm 0.022$ & 0.64 & 0.85 \\
\hline $\begin{array}{c}\text { Helleboro odori- } \\
\text { Fagetum } \\
\text { moesiacae }\end{array}$ & $20.58^{b} \pm 1.667$ & 10.00 & 29.00 & $2.13^{b} \pm 0.119$ & 1.47 & 2.68 & $0.69^{b} \pm 0.023$ & 0.53 & 0.79 \\
\hline
\end{tabular}

* Different superscript letters represent statistically significant differences between mean values (Pvalue $<0.05)$

\section{Discussion}

The floristic structure of the forest phytocoenoses in the investigated area of Kosmaj is characterized by biodiversity consisting of 52 families, 133 genera, and 216 plant species. More than half of the plant species belong to the following ten families: Rosaceae, Lamiaceae, Fabaceae, Poaceae, Asteraceae, Apiaceae, Scrophulariaceae, Brassicaceae, Campanulaceae and Cyperaceae. This taxonomic structure of plants distributed by families completely coincides with the taxonomic structure of the flora of Serbia, which as a whole deviates to a certain extent from the spectrum of plant families of the Balkan Peninsula (Stevanović, 1999).

On a local scale, numerous environmental factors have been suggested to affect species richness of the herb layer in European forests, such as: light availability (Hardtle et al., 2003; Dormann, et al., 2020), soil condition (Hardtle et al., 2003, Chytrý et al., 2003; Axmanová et al., 2012), tree layer species composition (Barbier et al., 2008), forest management (Paillet et al., 2010; Boch et al., 2013), etc. The results of different studies indicate a strong relationship between the alpha diversity of deciduous broadleaf forests and energy-related variables such as temperature seasonality and annual precipitation, bedrock types, and terrain ruggedness (Večeřa et al., 2019). In terms of the number of species of oak-dominated communities, they are much richer in species than beech forests. Light availability may affect the species richness of the herb layer both directly through species pool effects and indirectly by its positive effect on 
productivity (Axmanová et al., 2012), which resulted in a greater number and cover of plants in the herb layer of bright oak forests. The mean species richness per plot $(900$ $\mathrm{m}^{2}$ ) in the oak forests of the investigated area is 29 to 38. Differences in the composition and number of species are mainly attributed to orographic and edaphic characteristics, which are generally considered to be good environmental predictors of vegetation patterns in deciduous oak forests at local scale (Reczyńska et al., 2015). According to Slezák and Axmanová (2016), the number of the recorded herb layer vascular plants in acidophilous and thermophilous oak forests in central Slovakia (Štiavnické vrchy Mts) was $12-48$ per plot $\left(400 \mathrm{~m}^{2}\right)$.

In the beech-dominated forest communities which occur in shaded sites, cold and wet conditions, the number of species and diversity are significantly lower. The composition and richness of vascular plants in beech forests are highly variable among European regions and habitats, but European beech forests are generally species-poor. It is wellknown that the wide and mighty crowns of tall beech trees make a large shade for plants in shrub and herb layers so that other species in these communities occur in smaller numbers and with a lower degree of presence. Therefore, the number of species and diversity of beech forests are generally lower compared to other types of forests. Beech forests of the submontane belt are physiologically very similar to mountain forests, but there are significant differences in their floristic composition. The characteristics of submontane beech forests that distinguish them from other forests are a larger number of mesophilic species of lower altitudes, as well as mixed xerophilous elements of adjacent oak forests. In the area of Kosmaj, on a total sampled area of $10,800 \mathrm{~m}^{2}, 73$ species of vascular flora were registered in pure beech forests and 78 in mixed beechsessile oak forests (on an area of $9,000 \mathrm{~m}^{2}$ ), while the average was about 21 species per sample area (min 10 to max 29). Slezák and Hrivnák (2019) recorded 95 vascular plants growing in beech-dominated forests (on an area of $10,000 \mathrm{~m}^{2}$ ), with an average of 15 species per sample area (min 6 to $\max 30$ ) in the area of central Slovakia. According to Ujházyová et al. (2016), the average species richness recorded in beech forests in the submontane zone up to $800 \mathrm{~m}$ above sea level was 23-26 per plot, which is a slightly higher number than here recorded.

In the oak-dominated communities, the Shannon-Wiener diversity index have similar values (2.86 to 3.16). As beech forests are typically monodominant stands, this homogeneity of tree species results in the low values of the Shannon index, which is confirmed here because the lowest value of this index was found in the monodominant beech community (2.13). In the mixed community of beech and sessile oak, this value is slightly higher and amounts to 2.32 . In beech and mixed beech-oak forests, the presence of other tree species has a favorable effect on the quality of humus and the richness of plant species (Godefroid et al., 2005), i.e., an increase in beech presence in the tree layer reduces the diversity of ground flora vegetation (Härdtle et al., 2003, Petritan et al., 2012; Mölder et al., 2014). The share of oak in the tree crown canopy, even in a small proportion (20\% of stand basal area) features higher biodiversity of species in the understorey (Dölle et al., 2017), which was also confirmed in our research.

A more even forest type is also more diverse. In the oak-dominated forest communities, the uniformity index values are alike (0.82-0.85) and indicate an even distribution of species within the investigated phytocoenoses. The lowest uniformity index was recorded in beech (0.69) and beech-sessile oak forests (0.74). 


\section{Conclusions}

The establishment and maintenance of protected serve as the backbone of global strategies to halt biodiversity loss. The results presented here provide insight into the diversity of natural deciduous forests in the Kosmaj protected area. The results of the research indicate that oak-dominated forest communities are much richer and more diverse in composition than beech forests. Forest plant richness, diversity, and evenness were higher in oak forests than in beech forests (pure or mixed). The average number of species per forest community was 21 to 38, Shannon-Wiener index $\left(H^{\prime}\right)$ ranged from 2.13 to 3.16 and species evenness ranged from 0.69 to 0.85 . The rich biodiversity of the study area of Mt. Kosmaj is proved by the fact that the forest vegetation within the study area has a total of 216 plant species, classified into 133 genera and 52 families.

Considering the threats to floristic biodiversity, conservation actions must be enhanced to preserve the plant species and communities. Findings of the present study might have significant implications in prioritizing biodiversity conservation areas of different forest types, undertaking silvicultural operations, and selecting sites or enrichment planting. It is recommended to apply forest management practices that will affect the maintenance of plant diversity in these forest communities. Conservation treatments should promote less intensive silvicultural practices, which can provide greater forest structural complexity and small-scale variability, as well as a higher diversity of species with associated benefits for forest biodiversity.

We recommend further research to identify which silvicultural treatments and forest management practised in these forest types enrich community composition through habitat-specific species.

Acknowledgments. This study was funded by the Ministry of Education, Science, and Technological Development, Contract No. 451-03-9/2021-14/200027.

\section{REFERENCE}

[1] Axmanová, I., M. Chytrý, D. Zelený, C.F. Li, M. Vymazalová, J. Danihelka, M. Horsák, M. Kočí, S. Kubešová, Z. Lososová, Z. Otýpková, L. Tichý, V.B. Martynenko, E.Z. Baisheva, B. Schuster and M. Diekmann (2012): The species richness productivity relationship in the herb layer of European deciduous forests. Global Ecology and Biogeography 21: 657-667.

[2] Barbier, S., Gosselin, F., Balandier, P. (2008): Influence of tree species on understory vegetation diversity and mechanisms involved - A critical review for temperate and boreal forests. - Forest Ecology and Management 254: 1-15.

[3] Boch S., Prati D., Müller J., Socher S., Baumbach H., Buscot F., Gockel S., Hemp A., Hessenmoller D., Kalko E.K.V., Linsenmair K.E., Pfeiffer S., Pommer U., Schoening I., Schulze E.D., Seilwinder C., Weisser W.W., Wells K., Fischer M. (2013): High plant species richness indicates management-related disturbances rather than the conservation status of forests. - Basic and Applied Ecology 14 (6): 496-505.

[4] Braun-Blanquet, J. (1964): Pflanzensoziologie, Grundzüge der Vegetationskunde. 3rd ed. -Springer, Wien, New York.

[5] Chytrý, M., Tichý, L., Roleček, J. (2003): Local and regional patterns of species richness in Central European vegetation types along the $\mathrm{pH} / \mathrm{calcium}$ gradient.-Folia Geobot 38:429-442. 
[6] Dölle, M., Petritan, A.M., Biris, I.A., Petritan,I.C. (2017): Relations between tree canopy composition and understorey vegetation in a European beech-sessile oak old growth forest in Western Romania. - Biologia 72: 1422-1430.

[7] Dormann, C.F., Bagnara, M., Boch, S., Hinderling, J., Janeiro-Otero, A., Schäfer, D., Schall, P., Hartig, F. (2020): Plant species richness increases with light availability, but not variability, in temperate forests understorey. - BMC Ecol 20 (43).

[8] Godefroid, S., Massant, W., Koedam, N. (2005): Variation in the herb species response and the humus quality across a 200 -year chronosequence of beech and oak plantations in Belgium. - Ecography 28: 223-235.

[9] Guadilla-Sáez, S., Pardo-de-Santayana, M., Reyes-García, V., Svenning, J-C. (2019): Biodiversity conservation effectiveness provided by a protection status in temperate forest commons of north Spain. - Forest Ecology Management 433: 656-666.

[10] Härdtle, W., von Oheimb, G., Westphal, C. (2003): The effects of light and soil conditions on the species richness of the ground vegetation of deciduous forests in northern Germany (Schleswig-Holstein). - Forest Ecology Management 182:327-38.

[11] Lepš, J., Šmilauer, P. (2003): Multivariate Analysis of Ecological Data using CANOCO. -Cambridge: Cambridge University Press.

[12] Mölder, A., Streit, M., Schmidt, W. (2014): When beech strikes back: How strict nature conservation reduces herb-layer diversity and productivity in Central European deciduous forests. - Forest Ecology and Management 319:51-61.

[13] Morales-Hidalgo, D., Oswalt, S., E. Somanathan, E. (2015): Status and trends in global primary forest, protected areas, and areas designated for conservation of biodiversity from the Global Forest Resources Assessment 2015. - Forest Ecology and Management 352: 68-77.

[14] Paillet, Y., Bergès, L., Hjältén, J., Odor, P., Avon, C., Bernhardt-Römermann, M., Bijlsma, RJ., De Bruyn, L. Fuhr, M., Grandin ,U., Kanka, R., Lundin, L., Luque, S., Magura, T., Matesanz, S., Mészáros, I., Sebastià, M.T., Schmidt, W., Standovár, T., Tóthmérész, B., Uotila, A., Valladares, F., Vellak, K., Virtanen, R. (2010): Biodiversity differences between managed and unmanaged forests: meta-analysis of species richness in Europe. - Conservation Biology 24(1):101-12.

[15] Pérez-Valladares, C., Velázquez, A., Moreno-Calles, A, Mas, J., Torres-García, I., Casas, A., Rangel-Landa, S., Blancas, José, Vallejo, M., Téllez-Valdés, O. (2019): An expert knowledge approach for mapping vegetation cover based upon free access cartographic data: the Tehuacan-Cuicatlan Valley, Central Mexico. - Biodiversity and Conservation 28: 1361-1388.

[16] Petritan, A.M., Biris, I.A., Merce, O., Turcu, D.O., Petritan, I.C. (2012): Structure and diversity of a natural temperate sessile oak (Quercus petraea L.) - European Beech (Fagus sylvatica L.) forest. - Forest Ecology and Management 280: 140-149.

[17] Pielou, E.C. (1975): Ecologocal diversity. - John Wiley\& Sons, New York.

[18] Reczyńska, K. (2015): Diversity and ecology of oak forests in SW Poland (Sudetes Mts.). -Phytocoenologia 45: 85-106.

[19] Shannon, C.E., Weaver, W. (1963): The mathematical theory of communications. University of Illinois Press, Urbana.

[20] Slezák, M., Axmanová, I. (2016): Patterns of plant species richness and composition in deciduous oak forests in relation to environmental drivers. - Community Ecology 17: 6170 .

[21] Slezák, M., Hrivnák, R. (2019): How do environmental variables shape plant species diversity and composition in beech forests of Central Slovakia? - Biologia 74: 12951301.

[22] Stajić, S. (2016): Determination of forest phytocoenoses of Kosmaj by combining the standard phytosociological method and photointerpretation. Doctoral dissertation, Faculty of Forestry, University of Belgrade, Belgrade. 
[23] Stevanović, V. (ed) (1999): The Red Data Book of Flora of Serbia 1 - extinct and critically endangered taxa. - Ministry of Environment of the Republic of Serbia, Faculty of Biology, University of Belgrade, Institute for Protection of Nature of the Republic of Serbia, Belgrade.

[24] Tichý, L. (2002): JUICE, software for vegetation classification.- Journal of Vegetation Science 13: 451-453.

[25] Tomić, Z., Rakonjac Lj. (2013): Forest Phytocenoses of Serbia. - Institute of Forestry and Faculty of Applied Ecology, Singidunum University, Belgrade.

[26] Ujházyová, M., Ujházy, K., Chytrý, M., Willner, W., Čiliak, M., Máliš, F., Slezak, M (2016): Diversity of beech forests vegetation it the Eastern Alps, Bohemian Massif and the Western Carpathians. - Preslia 88: 435-457.

[27] Vanderschaaf, C.L. (2008): Estimating understory vegetation response to multi-nutrient fertilization in Douglas-fir and ponderosa pine stands. - Journal of Forest Research 13: 43-51.

[28] Van Der Maarel, E. (1979): Transformation of cover-abundance values in phytosociology and its effects on community similarity. - Vegetatio 39 (2): 97-114.

[29] Večeřa, M., Divíšek, J., Lenoir, J., Jiménez-Alfaro, B., Biurrun, I., Knollová, I., Agrillo, E., Campos, JA., Carni, A., Jimenez, GC.,Cuk, M., Dimopoulos, P., Ewald, J.,FernandezGonzalez, F ., Gegout, JC ., Indreica, A., Jandt, U., Jansen, F., Kacki, Z., Rasomavicius, V., Reznickova, M., Rodwell, JS., Schaminee, JHJ., Silc, U.,Svenning, JC., Swacha, G., Vassilev, K., Venanzoni, R., Willner, W., Wohlgemuth, T., Chytry, M. (2019): Alpha diversity of vascular plants in European forests. - Journal of Biogeography 46 (9):19191935.

[30] Wohlgemuth, T., Moser, B., Brandli, U., Kull, P., Schutz, M. (2008): Diversity of forest plant species at the community and landscape scales in Switzerland. - Plant Biosystems 142 (3): 604-613. 